\title{
Quaternary paleoecology: Reconstructing past environments
}

Sonia L. Fontana' and Keith D. Bennett ${ }^{2}$

Jujuy, Argentina, 19-30 August 2013

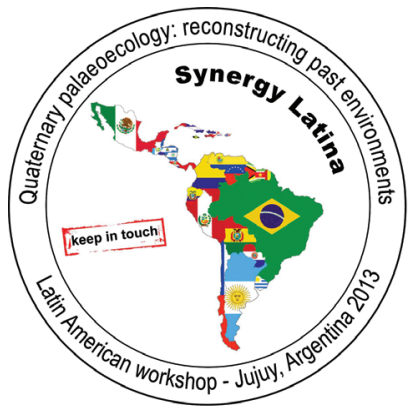

Paleoecological studies provide data on changes in vegetation and other aspects of the environment through time. Numerous paleoecological records from around the world have demonstrated that vegetation has changed, often dramatically, since the last glacial maximum (LGM). Changes are usually attributed to various external forcing factors, including climatic change, volcanic eruptions, fire, or human activity. Additionally, vegetation has changed as result of its own internal dynamics (Bennett and Willis 1995), which include migration, competition and succession across different timescales. An example of postglacial changes in vegetation from southern-most South America is illustrated in Figure 1; it specifies the different processes that have caused vegetation changes since the LGM (Fontana and Bennett 2012). Disentangling these forcing factors of environmental change is challenging, especially when they operate and interact at different spatial and temporal scales (Fontana et al. 2012).

The purpose of this workshop was to bring together Latin American researchers working on Quaternary environmental change to discuss and build up a network, exchange perspectives and promote international interactions. Forty-two senior and early career scientists, and postgraduate students from Mexico, Venezuela, Colombia, Brazil, Bolivia, Chile and Argentina attended the meeting. A broad range of expertise was represented covering palynology, diatoms, ostracods, foraminifera, nanoplankton, charophytes, phytoliths, dendrochronology, and archeology.

The workshop provided (1) an overview of the spatial and evolutionary responses of organisms to different Quaternary driving forces with the aim of providing insight into general questions of species survival, spread and biodiversity; (2) an outline of the principles, methods and applications of selected paleoecological techniques; and (3) an overview of methods and software used for data analyses.

The event comprised lectures, practical classes, poster presentations, a field trip and the development of a joint research project. The lectures addressed the paleoecology of the oceans, long Quaternary terrestrial records with multiple glacial-interglacial oscillations, an overview of key sites for the last glacial-interglacial transition, paleogenetics (including molecular clocks and ancient DNA), refugia, individualistic communities, plant migration, late Quaternary extinctions, and consideration of the role of Quaternary events on the

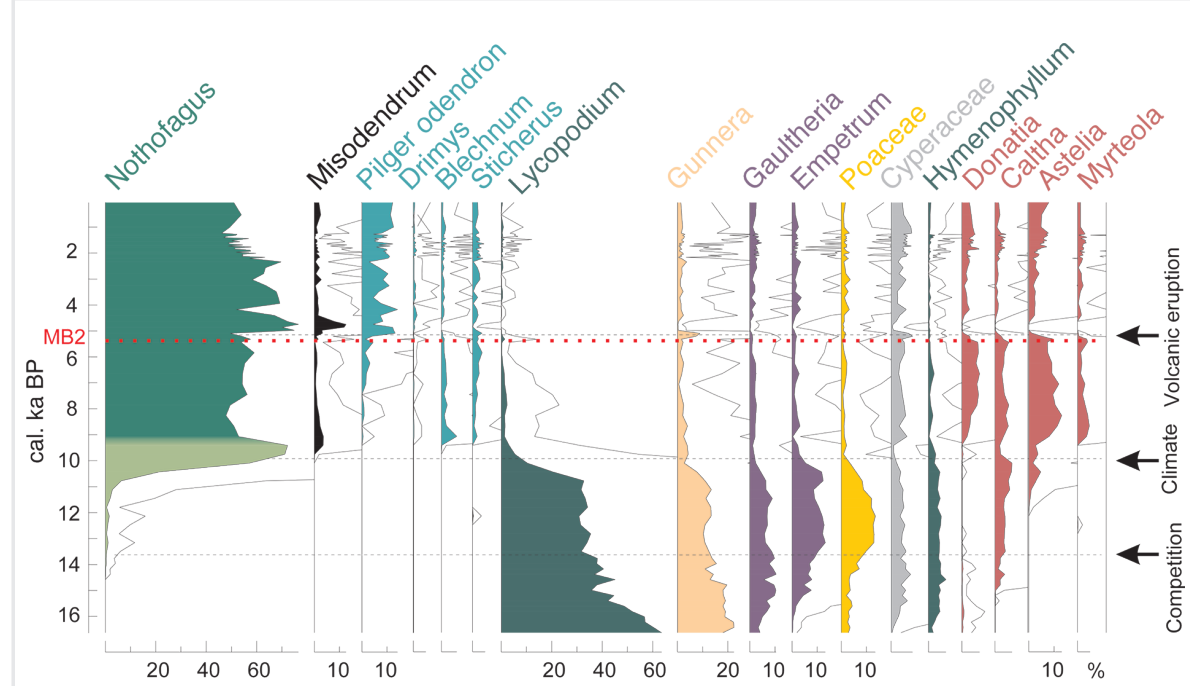

Figure 1: Pollen percentage diagram of selected taxa from Lake Ballena, indicating different processes that have caused main vegetation changes since the LGM. MB2 indicates the position of the tephra layer from the Mt Burney 2 eruption. Figure modified from Fontana and Bennett (2012).

evolution of organisms. Important discussions centered around data collection issues: site selection and coring, sub-sampling techniques, routine sediment analyses, overview of pollen and macrofossil analyses and the value of multi-disciplinary research in paleoenvironmental reconstructions. The practical classes focused on data handling: chronology, the radiocarbon method and calibration, zonation, rate of change, ordination techniques and diversity estimates.

A field trip to Laguna Rontuyoc took place, following which participants engaged in the Latin American co-operative project for young scientists, Synergy Latina, and designed a multi-disciplinary research project with the main goal being to disentangle possible interactions between the environment and humans of the Altiplano of northern Argentina. Attention was paid to the influence that climatic changes had on the development of Andean civilizations and the consequent impact of human activities on the landscape. The initial phase of this project was conducted during the course (describing and sub-sampling the sediment core), while the different analyses will be carried out at a later stage at the participants' home institutions.

This first workshop was hosted by the University of Jujuy and coordinated by Julio Kulemeyer and Liliana Lupo. It was a successful start to the task of enhancing paleoecological investigations in Latin America and we look forward to larger scale joint investigations, the ongoing exchange of knowledge leading to the development of new ideas and research questions, and continued cooperation. Further annual workshops are planned.

In addition to PAGES, participants received support from their home institutions, universities and research councils. The ${ }^{14} \mathrm{CHRONO}$ Centre at Queen's University Belfast, financially supported and ran the radiocarbon dating of the sediment records for the Synergy Latina project.

The full program of activities, including poster abstracts can be viewed at: www.uni-goettingen.de/en/413062.html.

\section{AFFILIATIONS}

'Department of Palynology and Climate Dynamics,

University of Göttingen, Germany

${ }^{2}$ School of Geography, Archaeology \& Palaeoecology,

Queen's University Belfast, Northern Ireland, UK

\section{CONTACT}

Sonia L. Fontana: Sonia.Fontana@biologie.uni-goettingen.de

\section{REFERENCES}

Bennett KD, Willis KJ (1995) Gior Bot Ital 129: 243-254

Fontana SL, Bennett KD (2012) Holocene 22: 1337-1350

Fontana SL et al. (2012) Holocene 22: 1203-1206 